\title{
The spatial distribution of canopy-resident and ground-resident cereal aphids (Sitobion avenae and Metopolophium dirhodum) in winter wheat
}

\author{
Linton Winder • Colin J. Alexander • \\ Chris Woolley $\cdot$ Joe N. Perry $\cdot$ John M. Holland
}

Received: 26 February 2012/ Accepted: 10 July 2012/Published online: 15 August 2012

(C) The Author(s) 2012. This article is published with open access at Springerlink.com

\begin{abstract}
We investigated, within two cereal fields in Southern England, the within-canopy spatial distribution of the aphids Sitobion avenae and Metopolophium dirhodum in relation to crop yield and plant nitrogen. We extended the study to investigate the spatial distribution of aphids that fell to, or returned from, the ground in order to estimate availability of the within-canopy aphid population to ground-active predators. We revealed that crop canopy aphid spatial pattern was associated with nitrogen or yield. Differences were evident between species: $S$. avenae was generally negatively associated with yield or plant nitrogen, whilst $M$. dirhodum exhibited positive association. For both aphid species, we observed strong spatial pattern for aphids falling to the ground and conclude that this could, in
\end{abstract}

Handling editor: Robert Glinwood

L. Winder $(\square)$

Department of Natural Sciences, Faculty of Social and Health

Sciences, Unitec Institute of Technology, Auckland,

New Zealand

e-mail: 1winder@unitec.ac.nz

\section{J. Alexander}

Biomathematics and Statistics Scotland, BioSS Office,

The James Hutton Institute, Invergowrie, Dundee, Scotland, UK

C. Woolley

41 Green End, Fen Ditton, Cambridge,

Cambridgeshire CB5 8SX, UK

\section{J. N. Perry}

Plant and Insect Ecology Division, Rothamsted Research,

Rothamsted, Harpenden, Herts, UK

J. M. Holland

Farmland Ecology Unit, Game and Wildlife Conservation Trust,

Fordingbridge, Hants SP6 1EF, UK part, mediate the effectiveness of ground-active predators as pest control agents.

Keywords Sitobion avenae - Metopolophium dirhodum . Fall-off · Integrated pest management $\cdot$ Cereal $\cdot$ Aphid

\section{Introduction}

Aphids are common pests of cereal crops and are known to have patchy within-field distributions (Alexander et al. 2005; Winder et al. 2001; Winder et al. 1999). Such patchy distributions are important because spatial pattern is likely to mediate the amount of damage caused by aphids through direct yield loss (Möwes et al. 1997), reduction in quality (Basky and Fónagy 2007) or virus transmission (Chapin et al. 2001). Spatial pattern will also influence the interaction between aphids and the natural enemies that contribute to their suppression or control (Harwood et al. 2001; Winder et al. 2005). Two aphid species are most commonly found in U.K. cereals: the English grain aphid Sitobion avenae (Fabricius, 1775) and the rose grain aphid Metopolophium dirhodum (Walker, 1849). S. avenae is predominantly an ear-feeding species (thus affecting yield or crop quality directly), whilst $M$. dirhodum feeds on leaves and is considered to be a less important pest because it has a lower impact on yield (Dixon 1987; van Emden and Harrington 2007).

Crop husbandry is known to influence the population development of aphids within cereal crops, and increased nitrogen content can enhance aphid population development (Aqueel and Leather 2011; Chaul et al. 2005; Honêk and Martinková 2002; Rowntree et al. 2010), which are also increased by the application of nitrogen fertiliser (Duffield et al. 1997; Ehsan-Ul-Haq and van Emden 2002; 
Khan and Port 2008), although the effects are often variable. Therefore, if crop nitrogen influences aphid population growth, its within-field variability (Delin 2004) may contribute to aphid spatial distributions. The first part of this study investigated the spatial distribution of cereal aphids infesting the crop and used yield and crop nitrogen measurements as simple indicators of crop quality. We hypothesised that aphid spatial pattern would be associated with these host plant characteristics and also measured soil moisture as it is known to influence aphid development (Ehsan-Ul-Haq and Van Emden 2003) and epigeal natural enemy spatial pattern (Holland et al. 2007).

The second part of this study investigated the spatially explicit distribution of aphids that are falling to, or returning from, the ground, hypothesising that these distributions would be closely linked. Aphids are know to have a defence mechanism whereby they fall to the ground in response to their natural enemies or alarm pheromones (Irwin et al. 2007), and they are also probably dislodged by mechanical means through movement of the crop. The dislodged aphids rarely return to the same host plant. The rate at which aphids fall to the ground has been well studied, and in wheat it is known that this process affects a significant proportion of the canopy-resident aphid population, with reported fall-off rates ranging from $20 \%$ to $95 \%$ day $^{-1}$ and typically in the range of $20-35 \%$ day $^{-1}$ (Kerzicnik et al. 2010; Sopp et al. 1987; Sunderland et al. 1986; Winder 1990; Winder et al. 1994). Thus, the number of dislodged aphids often exceeds the number that are directly predated or parasitised (Minoretti and Weisser 2000).

Due to this turnover, the aphid population is divided into canopy-resident and ground-resident subpopulations. Spatial separation of these subpopulations provides a mechanism for niche partitioning (Finke and Snyder 2008), whereby multiple predator species act on a single target prey. Some natural enemies such as syrphids (Diptera: Syrphidae) and coccinellids (Coleoptera: Coccinellidae) attack aphids directly on their host plant within the crop canopy, whilst a multitude of ground-active predators such as carabids (Coleoptera: Carabidae) and some linyphiids (Araneae: Linyphiidae) actively consume aphids whilst they are on the soil surface (Sunderland et al. 1986; Symondson et al. 2002). Ground-resident aphids may die before they reach a new host and are exposed to considerable predation pressure that can subsequently affect aphid spatial distribution and the spread of aphid-borne viruses (Annan et al. 1999). Virtually nothing is known about aphid fall-off in spatially explicit terms, yet it is known that predatory success of ground-active species such as Pterostichus cupreus (Coleoptera: Carabidae) is dependent on the spatial distribution of their prey (Bommarco et al. 2007).

\section{Methods}

Field methods

We monitored the distribution of cereal aphids in two conventionally managed winter wheat fields (Horseparks, 8.1 ha, and Oakmead, 5.4 ha sown in mid-October 2001 with the variety 'Claire') located within $500 \mathrm{~m}$ of each other at Seale-Hayne Agricultural College, Devon, Southern England. No insecticides were applied to the fields during the study. A sampling grid was established within each field. In both fields, a grid of 82 sampling locations in an offset pattern was set up within an area of $120 \mathrm{~m}$ by $168 \mathrm{~m}$ (Fig. 1). An accurate location $(<1 \mathrm{~m})$ for each sampling point was established by a handheld GPS unit (Trimble Geoexplorer 3, Trimble Navigation Ltd, Sunnyvale, California, USA), and each location was designated with a flexicane extending beyond crop height with a waterproof card bearing its location number. In order to prevent lodging of the crop by trampling, a narrow path was cut with a 'strimmer' from tractor wheel tracks to each sampling location. Twenty-five tillers were individually marked (using small waterproof cards tied to each tiller) at each location within a $0.5-\mathrm{m}^{2}$ area. Aphid counts, recording species and number by direct observation, were taken on the 25 marked tillers on five occasions in Horseparks and six occasions in Oakmead. Crop growth stage following the method of Zadoks et al. (1974) was also recorded. Sample dates were planned at weekly intervals, but the actual day on which counts were made were weather dependent and were only conducted on fine days. Aphid counts for each location were calculated by averaging the 25 individual counts, and aphid densities (number $\mathrm{m}^{-2}$ ) were generated by combining the count data with crop density measurements. Additionally, aphid loading during the growing season was calculated by calculating 'aphid days' for each sampling location following the method of Ruppel (1983).

When the crop had matured and was ready for harvest, plants were collected at each sampling location from an area of $0.1 \mathrm{~m}^{2}$ and crop density (ears $\mathrm{m}^{-2}$ ), yield $\left(\mathrm{g} \mathrm{m}^{-2}\right.$ ), $\%$ grain $\mathrm{N}$ and $\%$ leaf $\mathrm{N}$ determined. Nitrogen levels were determined using a Leco Nitrogen Analyser; three ears and three leaves were sampled, dried to a constant weight and ground prior to analysis. Additionally, soil moisture was recorded on one occasion (26 July); for each sampling location, three soil moisture recordings were made to a depth of $5 \mathrm{~cm}$ using a hand-held probe (ThetaProbe Soil Moisture Sensor, Delta-T, Cambridge, UK) and then averaged to provide a single value.

Aphid fall-off was also measured. Five $245 \mathrm{~mm} \times 95 \mathrm{~mm}$ sticky traps (cut from PestWest electrocutor sheeting supplied by Agrisense) were placed horizontally at each location and sampling occasion for $24 \mathrm{~h}$. Following 

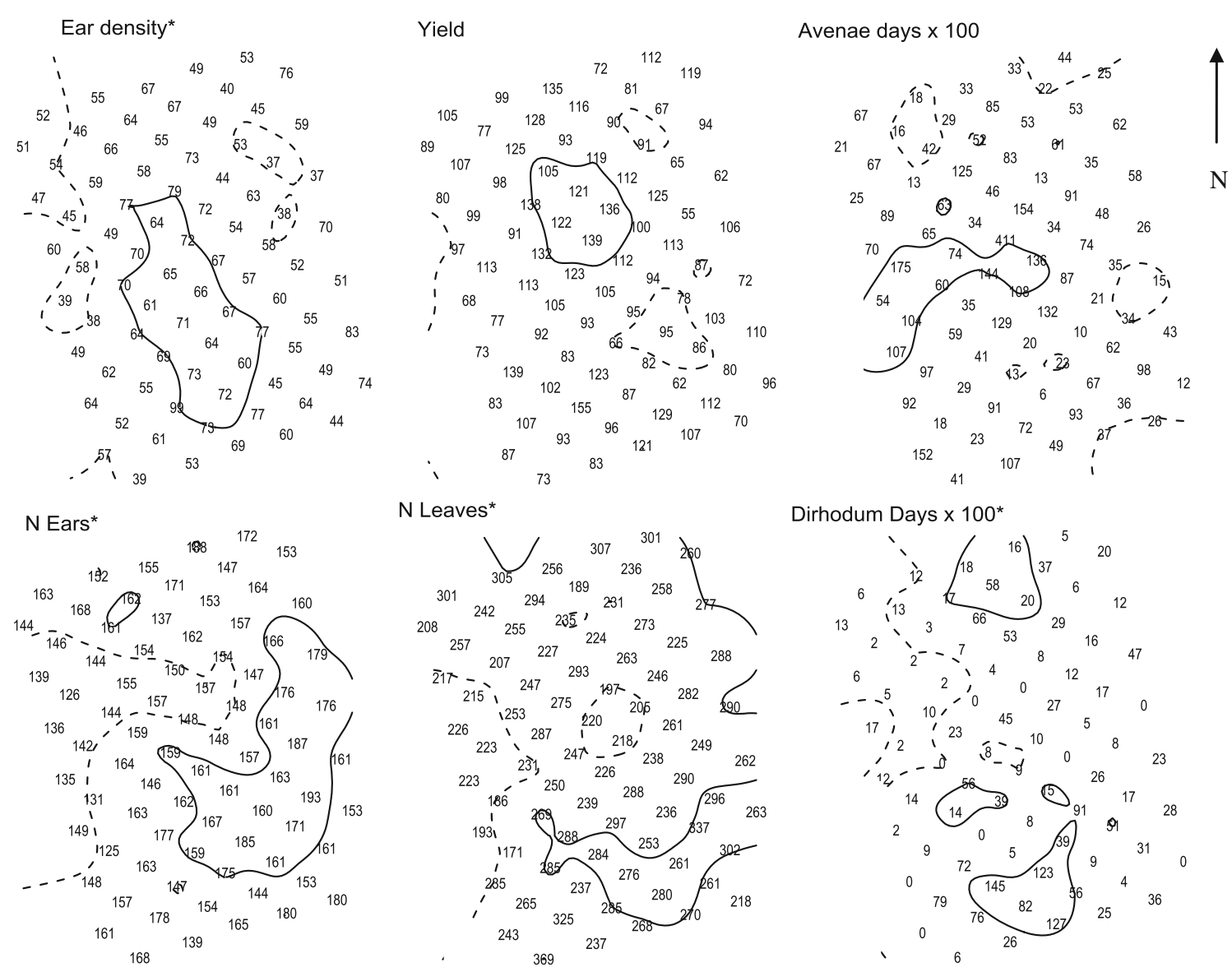

Fig. 1 Spatial pattern of ear density (number $\mathrm{m}^{-2}$ ), yield $\left(\mathrm{g} \mathrm{m}^{-2}\right)$, $\% \mathrm{~N}$ in ears, $\% \mathrm{~N}$ in leaves, S. avenae aphid days and $M$. dirhodum aphid days for the field Horseparks. The map contours indicate clusters of relatively large counts (areas bounded by solid line) or

removal, the numbers of aphids were recorded (discounting aphids found on the extreme edge of the sticky material in case they had climbed directly onto the sheeting), and the number caught (number $\mathrm{m}^{-2} \mathrm{day}^{-1}$ ) was calculated by pooling data from the five traps for each location and then correcting to $\mathrm{m}^{-2}$. Means for each sample date were calculated by averaging values from the 82 sampling locations. Regression was done to determine the relationship between mean aphid density within the crop canopy and the mean rate of aphid fall-off (number falling $\mathrm{m}^{-2}$ day $^{-1}$ ), pooling the data from the two fields.

In addition, the re-climbing of plants by aphids was recorded on one occasion (5th July) in the field Horseparks. Twenty climbing traps were positioned at each sampling location, the design of the traps following that of Winder (1990). Each trap was constructed from a $200 \mathrm{~mm}$ length of dowelling with an inverted plastic bottle $(18 \mathrm{~mm}$ wide, $48 \mathrm{~mm}$ long) placed over the stick at one end to prevent it from getting wet. High-tack adhesive tape $(25 \mathrm{~mm}$ wide, manufactured by $3 \mathrm{M}$, product code 927) was wrapped 'patches', for which $v_{\mathrm{i}}>1.5$, and small counts (areas bounded by hatched line), for which $v_{\mathrm{j}}<-1.5$. *Denotes where measurable spatial pattern could be detected

around the stick and served to trap the aphids as they attempted to climb and re-enter the crop canopy.

\section{Spatial analysis}

Spatially explicit representations of these data were constructed using Spatial Analysis by Distance Indices (SADIE) utilising 'red-blue' plot methodology (Perry and Dixon 2002; Winder et al. 2001; Perry et al. 1999). Redblue plots provided a means of visualising neighbourhoods of consistently high counts (patches) or consistently low counts (gaps) within the area being studied. When using this method, patches are usually shown in red and represent neighbourhoods of counts higher than the sample mean, $\mathrm{m}$. Gaps are usually shown in blue and represent neighbourhoods of counts lower than the sample mean $\mathrm{m}$. In this analysis, 'red' patches or 'blue' gaps were represented by areas bounded by solid or hatched lines, respectively, to provide monochrome representation. 
At a given location, each sampling unit had an $\mathrm{x}$, $\mathrm{y}$ field coordinate and a corresponding count $\mathrm{c}$, which represented the value of the variable being analysed. Using these data, we generated SADIE red-blue plots for the aphid data, soil moisture, yield and nitrogen measurements. Data were integerised if required as values must be used in this format and the nonparametric option was used for aphid counts as the variance greatly exceeded the mean. Each sampling unit was ascribed an index of clustering: either a positive $v_{\mathrm{i}}$ index for patch units with $\mathrm{c}_{\mathrm{i}}>\mathrm{m}$ or a negative $v_{\mathrm{j}}$ index for gap units with $\mathrm{c}_{\mathrm{j}}<\mathrm{m}$. The cluster values were then used to generate contour maps that show patch and/or gap neighbourhoods. We used SadieShell version 2.0 (available for download at http://home.cogeco.ca/ sadiespatial/index. html) for all analyses and maps were generated in Surfer 10 (Golden Software).

Pairwise comparison of red-blue plots allowed spatial similarity between variables to be determined, described in terms of local 'association' or 'dissociation'. The method effectively overlays the two red-blue plots and determines whether there is correspondence at the local (sampling unit) scale, after allowing for spatial autocorrelation (Dutilleul 1993). Local association indicated correspondence between cluster types (i.e. there was measurable patch-patch and/or gap-gap cluster index coincidence), whilst local dissociation indicated that the opposite was the case (i.e. there was measurable patch-gap or gap-patch coincidence).

Tests for local spatial association were conducted by paired (bivariate) comparisons using N_AShell (version 1, also downloadable). Local spatial association was measured using the index $\chi_{\mathrm{k}}$, the statistic being based on the similarity between the clustering indices drawn from the two data sets. $\chi_{\mathrm{k}}$ was positive if local association was evidently present due to similarity of cluster indices $\left(v_{\mathrm{k}} / v_{\mathrm{k}}\right.$ or $-v_{\mathrm{k}} /-v_{\mathrm{k}}$ ) and negative if local dissociation was present $\left(v_{\mathrm{k}} /-v_{\mathrm{k}}\right.$ or $\left.-v_{\mathrm{k}} / v_{\mathrm{k}}\right)$. An overall spatial association statistic $\mathrm{X}$ was calculated from the mean of these local values, equivalent to a simple correlation coefficient, and was positive when association was evident and negative for dissociation (Winder et al. 2001). The method provided a formal test of significance; $P<0.025$ for association, whilst $P>0.975$ for dissociation.

\section{Results}

\section{Crop characteristics}

For the field Horseparks, mean crop density ( \pm 1 s.e.) was $593.5 \pm 13.3$ ears $\mathrm{m}^{-2}$. Strong spatial pattern was evident; density was measurably higher within the centre of the field (Fig. 1; Table 1). Mean yield was $993.1 \pm 23.6 \mathrm{~g} \mathrm{~m}^{-2}$, and no measurable spatial pattern could be detected, although there was some indication that high yields occurred centrally. Mean ear and leaf nitrogen was $1.58 \% \pm 0.02$ and $2.57 \% \pm 0.04$, respectively. Nitrogen in ears and leaves were locally associated $(\chi=0.44$, $P<0.01$ ), and both exhibited very strong spatial pattern, with gap areas on the western side of the field and patches towards the east. Strong local association was evident between yield and ear nitrogen levels $(\chi=0.71$, $P<0.01)$. Mean soil moisture was $10.43 \% \pm 0.01$ and exhibited strong spatial pattern (Table 1), although it was not locally associated with any other measured variable.

For the field Oakmead, mean crop density was $539.4 \pm 12.3$ ears $\mathrm{m}^{-2}$ with a measurable patch along the western edge of the field (Fig. 2; Table 1). Mean yield was $958.6 \pm 19.6 \mathrm{~g} \mathrm{~m}^{-2}$, although no measurable spatial pattern was evident. Mean ear and leaf nitrogen was $1.8 \% \pm 0.1$ and $2.9 \% \pm 0.1$, respectively. Nitrogen in ears and leaves was locally associated $(\chi=0.77$, $P<0.01)$ and exhibited strong spatial pattern, with a gap area on the western edge of the field and patch areas centrally. Strong local association between yield and ear nitrogen was evident $(\chi=0.68, P<0.01)$. Mean soil moisture was $8.69 \% \pm 0.01$ and exhibited strong spatial pattern (Table 1), although it was not locally associated with any other measured variable.

Table 1 Mean cluster index $v_{\mathrm{i}}$ for patches and $v_{\mathrm{j}}$ for gaps, with associated probability, $\mathrm{P}$, for tiller density $\left(\right.$ number $\left.\mathrm{m}^{-2}\right), \mathrm{yield}\left(\mathrm{g} \mathrm{m} \mathrm{m}^{-2}\right), \%$ nitrogen in ears and \% nitrogen in leaves for the two fields Horseparks and Oakmead

\begin{tabular}{|c|c|c|c|c|c|c|c|c|c|c|c|}
\hline \multirow[t]{2}{*}{ Field } & \multirow{2}{*}{$\begin{array}{l}\text { Cluster } \\
\text { type }\end{array}$} & \multicolumn{2}{|c|}{ Crop density } & \multicolumn{2}{|l|}{ Yield } & \multicolumn{2}{|l|}{ N (ears) } & \multicolumn{2}{|c|}{ N (leaves) } & \multicolumn{2}{|c|}{ Soil moisture } \\
\hline & & $\begin{array}{l}\text { Cluster } \\
\text { index }\end{array}$ & $P$ & $\begin{array}{l}\text { Cluster } \\
\text { index }\end{array}$ & $P$ & $\begin{array}{l}\text { Cluster } \\
\text { index }\end{array}$ & $P$ & $\begin{array}{l}\text { Cluster } \\
\text { index }\end{array}$ & $P$ & $\begin{array}{l}\text { Cluster } \\
\text { index }\end{array}$ & $P$ \\
\hline \multirow[t]{2}{*}{ Horseparks } & Patch & 1.42 & $0.02 *$ & 1.15 & 0.14 & 1.78 & $<0.01 *$ & 1.41 & $0.02 *$ & 2.42 & $<0.01 *$ \\
\hline & Gap & -1.24 & 0.07 & -1.15 & 0.16 & -1.65 & $<0.01 *$ & -1.26 & 0.06 & -2.34 & $<0.01 *$ \\
\hline \multirow[t]{2}{*}{ Oakmead } & Patch & 1.49 & $<0.01^{*}$ & 1.29 & 0.06 & 1.48 & $0.01 *$ & 1.78 & $<0.01 *$ & 1.34 & n.s. \\
\hline & Gap & -1.59 & $<0.01^{*}$ & -1.23 & 0.09 & -1.58 & $<0.01 *$ & -1.68 & $<0.01 *$ & -1.19 & $0.04 *$ \\
\hline
\end{tabular}

*Denotes where measurable spatial pattern could be detected 
Table 2 Crop growth stage (GS, Zadoks scale), aphids tiller ${ }^{-1}$ (per tiller) and $\mathrm{m}^{-2}$ (density) within the crop canopy and number of aphids falling to the ground $\mathrm{m}^{-2}$ day $^{-1}$ (fall-off) from the fields Horseparks and Oakmead

\begin{tabular}{|c|c|c|c|c|c|c|c|}
\hline \multirow[t]{2}{*}{ Date } & \multirow[t]{2}{*}{ GS } & \multicolumn{3}{|l|}{ S. avenae } & \multicolumn{3}{|l|}{ M. dirhodum } \\
\hline & & Per tiller & Density $\mathrm{m}^{-2}$ & Fall-off & Per tiller & Density & Fall-off \\
\hline \multicolumn{8}{|c|}{ Horseparks } \\
\hline 9 June & 59 & $1.40 \pm 0.4$ & $30.9 \pm 7.7$ & $9.8 \pm 1.5$ & $5.6 \pm 0.8$ & $131.0 \pm 18.5$ & $54.7 \pm 10.8$ \\
\hline 13 June & 60 & $3.2 \pm 0.5$ & $73.3 \pm 12.4$ & $23.5 \pm 3.0$ & $7.9 \pm 1.1$ & $189.5 \pm 27.6$ & $43.1 \pm 4.5$ \\
\hline 28 June & 71 & $13.5 \pm 1.4$ & $318.1 \pm 37.4$ & $117.3 \pm 10.3$ & $1.3 \pm 0.3$ & $34.0 \pm 10.0$ & $27.3 \pm 2.9$ \\
\hline 5 July & 75 & $11.6 \pm 1.3$ & $275.4 \pm 32.5$ & $136.7 \pm 14.6$ & $0.3 \pm 0.1$ & $6.6 \pm 2.7$ & $35.4 \pm 9.0$ \\
\hline 10 July & 77 & $7.7 \pm 1.0$ & $175.3 \pm 23.1$ & $20.9 \pm 3.0$ & $0.2 \pm 0.1$ & $4.2 \pm 2.3$ & $5.5 \pm 1.1$ \\
\hline \multicolumn{8}{|l|}{ Oakmead } \\
\hline 9 June & 59 & $0.7 \pm 0.2$ & $16.5 \pm 5.6$ & $5.2 \pm 1.2$ & $4.5 \pm 0.7$ & $100.0 \pm 15.4$ & $20.0 \pm 2.6$ \\
\hline 16 June & 60 & $1.4 \pm 0.2$ & $30.5 \pm 5.4$ & $8.8 \pm 1.6$ & $6.5 \pm 0.9$ & $146.6 \pm 20.1$ & $25.1 \pm 2.8$ \\
\hline 23 June & 69 & $5.6 \pm 0.6$ & $119.2 \pm 12.9$ & $11.5 \pm 1.4$ & $1.5 \pm 0.3$ & $33.1 \pm 6.5$ & $29.9 \pm 2.7$ \\
\hline 30 June & 71 & $4.7 \pm 0.5$ & $99.4 \pm 10.3$ & $20.3 \pm 2.3$ & $0.8 \pm 0.3$ & $17.5 \pm 6.6$ & $11.5 \pm 1.4$ \\
\hline 5 July & 75 & $3.8 \pm 0.4$ & $76.8 \pm 7.0$ & $17.4 \pm 2.0$ & $0.48 \pm 0.15$ & $10.3 \pm 3.4$ & $22.5 \pm 5.7$ \\
\hline 14 July & 77 & $4.3 \pm 0.5$ & $84.8 \pm 9.6$ & $12.0 \pm 1.8$ & $0.2 \pm 0.1$ & $4.3 \pm 2.6$ & $6.2 \pm 1.1$ \\
\hline
\end{tabular}

Aphid values expressed as arithmetic mean ( \pm 1 s.e.)
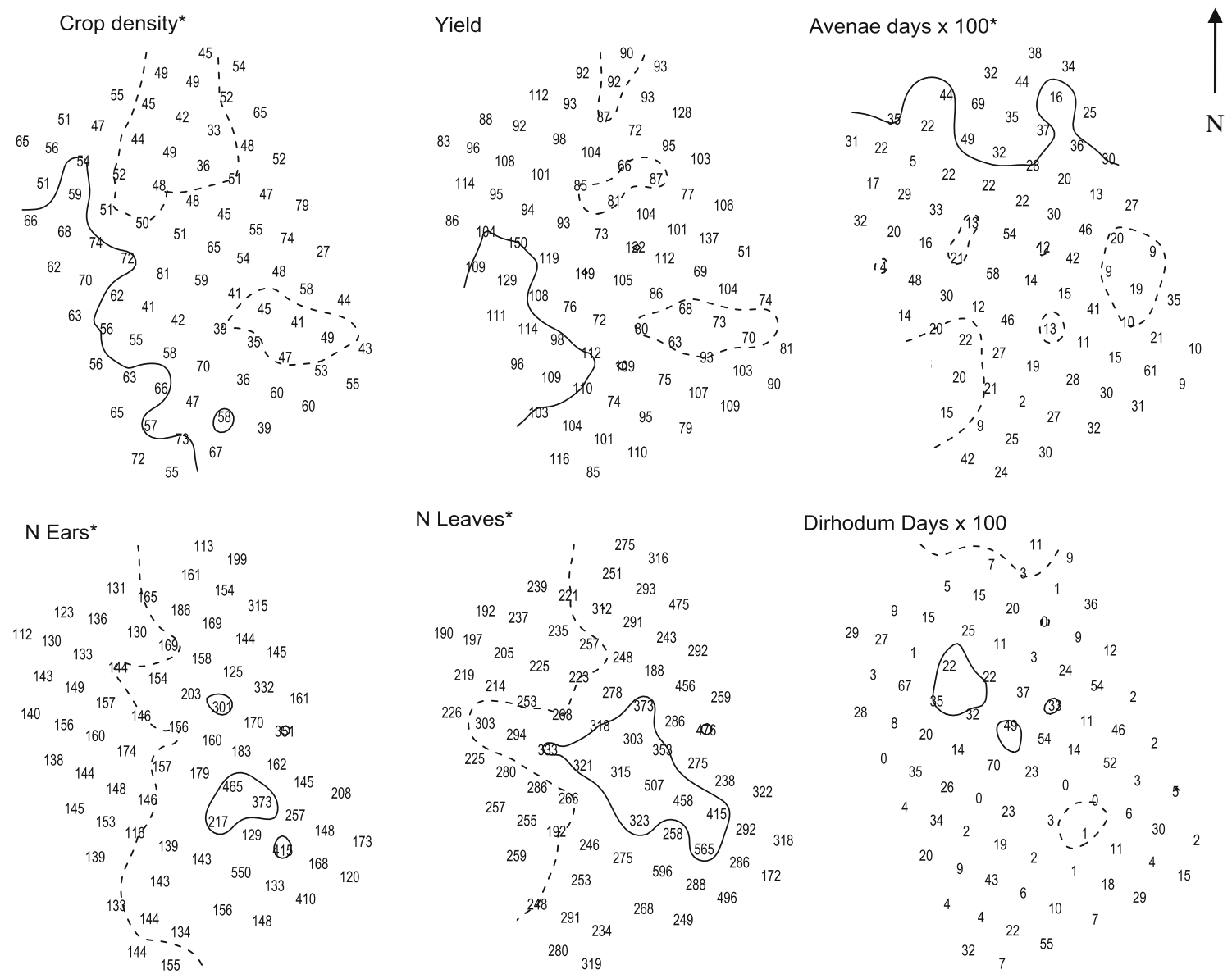

Fig. 2 Spatial pattern of ear density (number $\mathrm{m}^{-2}$ ), yield $\left(\mathrm{g} \mathrm{m}^{-2}\right), \% \mathrm{~N}$ in ears, $\% \mathrm{~N}$ in leaves, S. avenae aphid days and $M$. dirhodum aphid days for the field Oakmead 
Aphids within the crop canopy and falling to the ground

For Horseparks, S. avenae and M. dirhodum populations peaked on 28 June and 13 June, respectively (Table 2). The crop flowered in mid-June, and the $S$. avenae population was sufficiently high at this time to exceed the damage threshold of an increasing population of greater than five aphids tiller ${ }^{-1}$ (George and Gair 1979). For both species, spatial pattern within the crop was generally not evident. $S$. avenae fall-off exhibited significant spatial pattern on

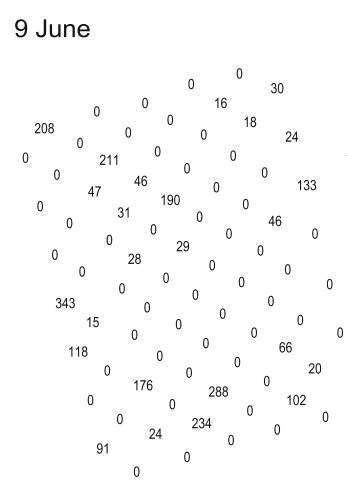

\section{June}

28 June

5 July

10 July*

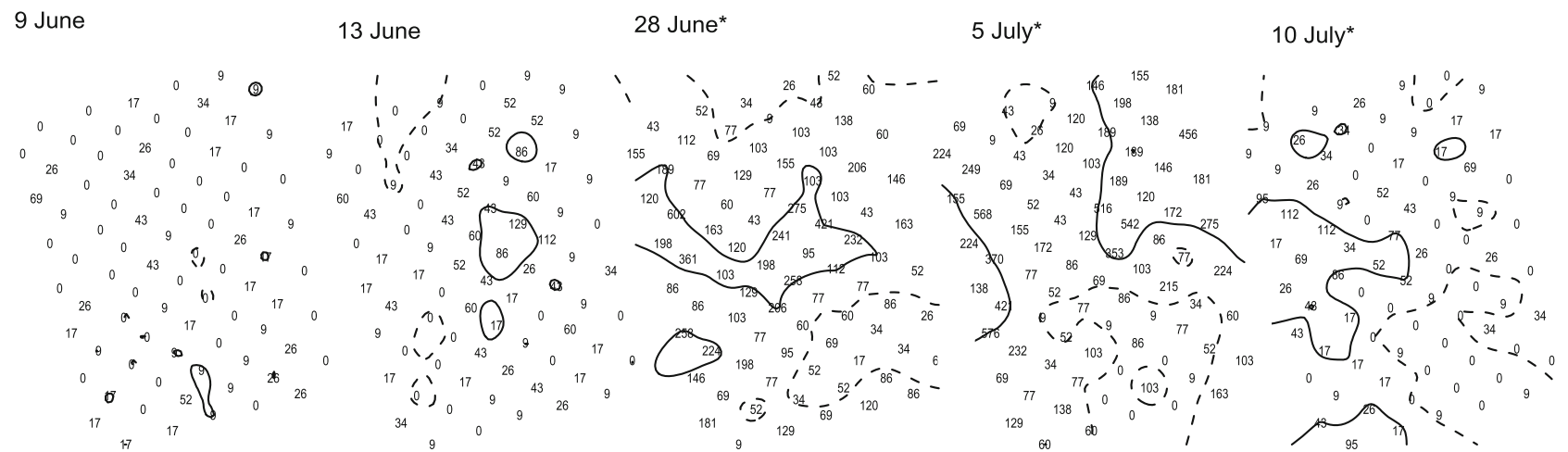

Fig. 3 Spatial pattern on each sampling date of S. avenae on the crop, number $\mathrm{m}^{-2}$ (upper series), and falling to the ground, number $\mathrm{m}^{-2}$ day ${ }^{-1}$ (lower series), for the field Horseparks

Table 3 Mean cluster index $v_{\mathrm{i}}$ for patches and $v_{\mathrm{j}}$ for gaps, with associated probability, $P$, for the aphids $S$. avenae and $M$. dirhodum found on the crop and on the ground within the field Horseparks

\begin{tabular}{|c|c|c|c|c|c|c|c|c|c|}
\hline \multirow[t]{2}{*}{ Date } & \multirow[t]{2}{*}{ Cluster type } & \multicolumn{2}{|c|}{ S. avenae-crop } & \multicolumn{2}{|c|}{ S. avenae-ground } & \multicolumn{2}{|c|}{ M. dirhodum — crop } & \multicolumn{2}{|c|}{ M. dirhodum-ground } \\
\hline & & Cluster index & $P$ & Cluster index & $P$ & Cluster index & $P$ & Cluster index & $P$ \\
\hline \multirow[t]{2}{*}{9 June } & Patch & 0.88 & 0.79 & 1.08 & 0.24 & 1.00 & 0.42 & 0.98 & 0.50 \\
\hline & Gap & -0.88 & 0.81 & -1.00 & 0.41 & -1.06 & 0.28 & -1.02 & 0.37 \\
\hline \multirow[t]{2}{*}{13 June } & Patch & 0.92 & 0.69 & 1.11 & 0.20 & 1.21 & 0.09 & 1.25 & 0.06 \\
\hline & Gap & -0.87 & 0.84 & -1.11 & 0.20 & -1.29 & $0.05 *$ & -1.23 & 0.08 \\
\hline \multirow[t]{2}{*}{28 June } & Patch & 1.13 & 0.18 & 1.41 & $0.01 *$ & 1.04 & 0.33 & 1.25 & 0.07 \\
\hline & Gap & -1.12 & 0.17 & -1.46 & $0.01 *$ & -1.06 & 0.28 & -1.27 & 0.06 \\
\hline \multirow[t]{2}{*}{5 July } & Patch & 1.24 & 0.07 & 1.70 & $<0.01 *$ & 1.07 & 0.26 & 1.01 & 0.38 \\
\hline & Gap & -1.24 & 0.14 & -1.76 & $<0.01 *$ & -1.07 & 0.27 & -1.04 & 0.33 \\
\hline \multirow[t]{2}{*}{10 July } & Patch & 1.83 & $<0.01 *$ & 1.62 & $<0.01 *$ & 1.03 & 0.39 & 1.14 & 0.14 \\
\hline & Gap & -1.86 & $<0.01 *$ & -1.61 & $<0.01 *$ & -1.01 & 0.35 & -1.14 & 0.15 \\
\hline \multirow[t]{2}{*}{ Aphid days } & Patch & 1.19 & 0.12 & - & - & 1.39 & $0.01 *$ & - & - \\
\hline & Gap & -1.25 & 0.07 & - & - & -1.45 & $0.02 *$ & - & - \\
\hline
\end{tabular}

*Denotes where measurable spatial pattern could be detected 
9 June

13 June*

28 June
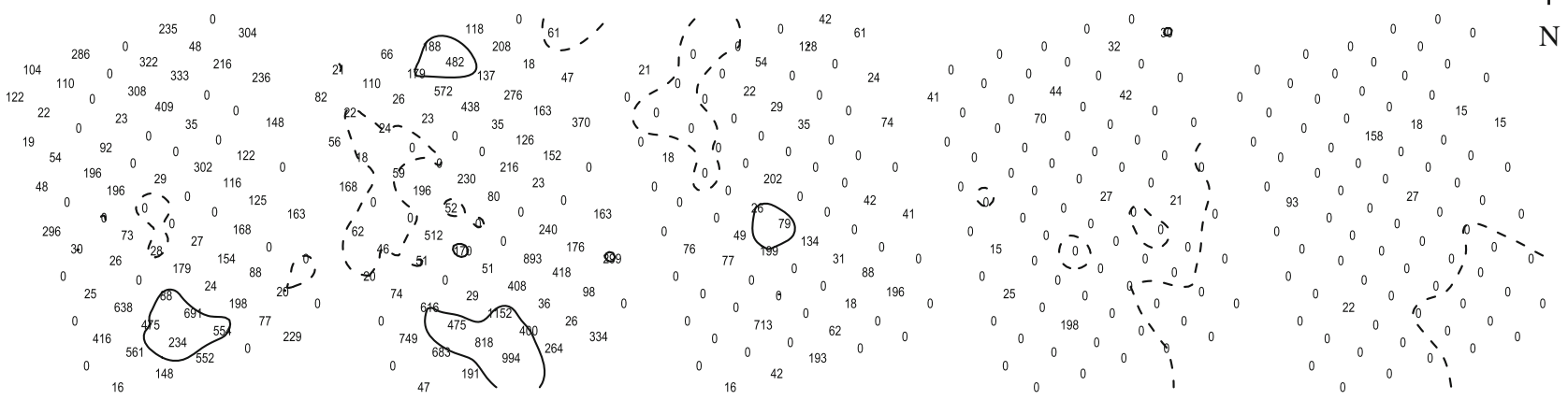

9 June

13 June

28 June

5 July

10 July

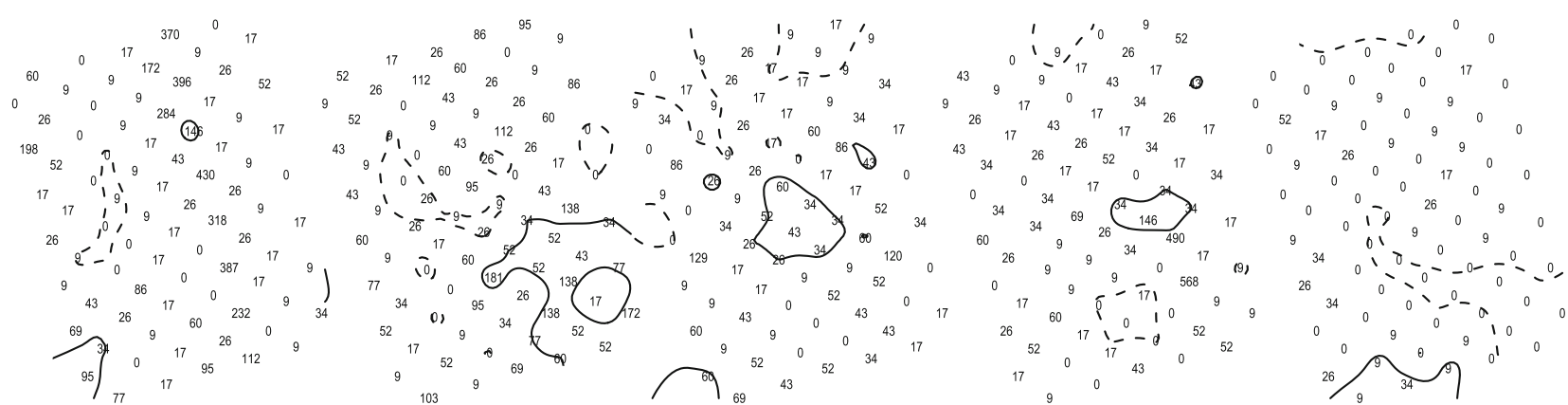

Fig. 4 Spatial pattern on each sampling date of M. dirhodum on the crop, number $\mathrm{m}^{-2}$ (upper series), and the ground, number $\mathrm{m}^{-2}$ day ${ }^{-1}$ (lower series), for the field Horseparks

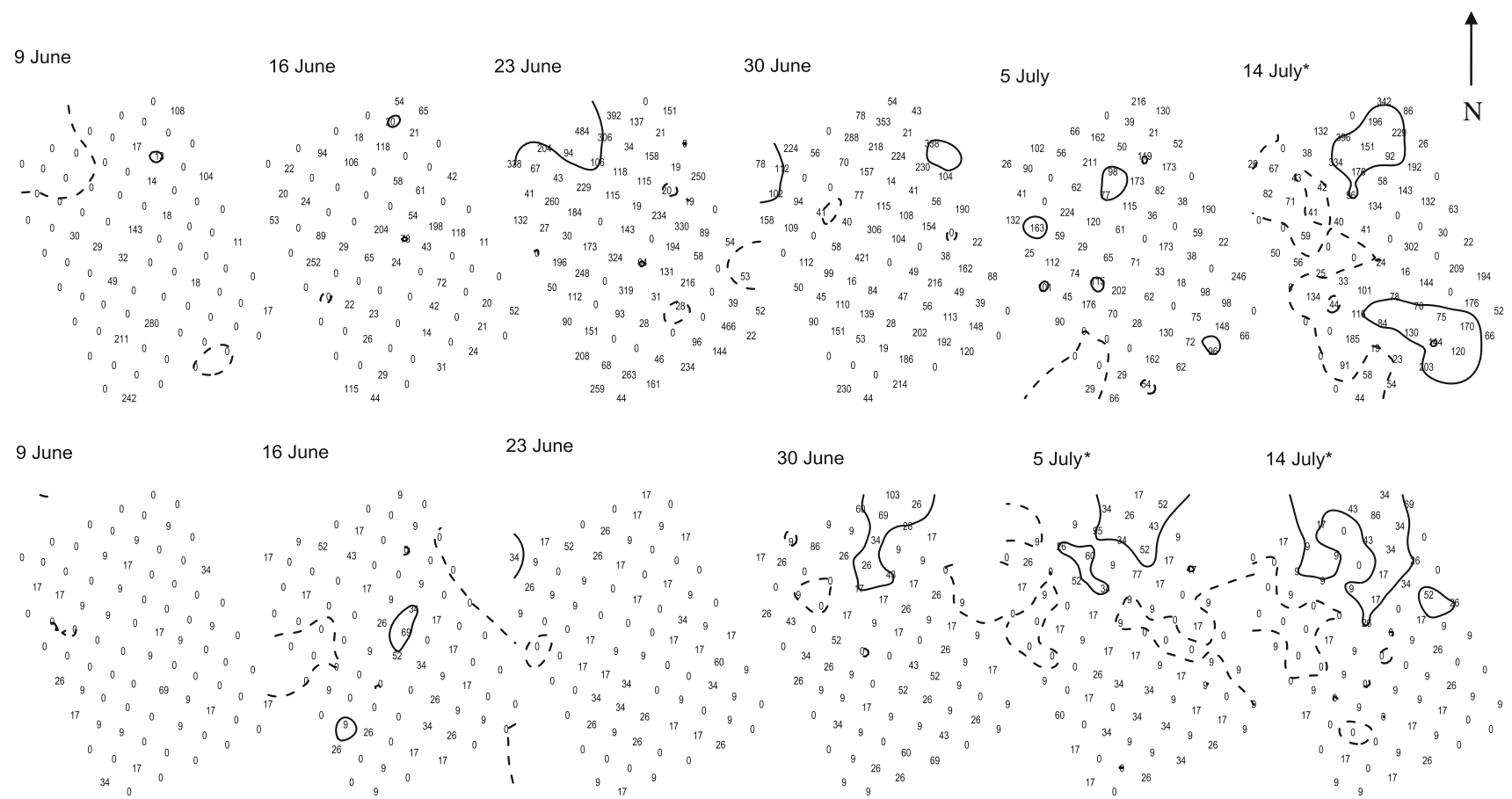

Fig. 5 Spatial pattern on each sampling date of S. avenae on the crop, number $\mathrm{m}^{-2}$ (upper series), and falling to the ground, number $\mathrm{m}^{-2}$ day $^{-1}$ (lower series), for the field Oakmead 


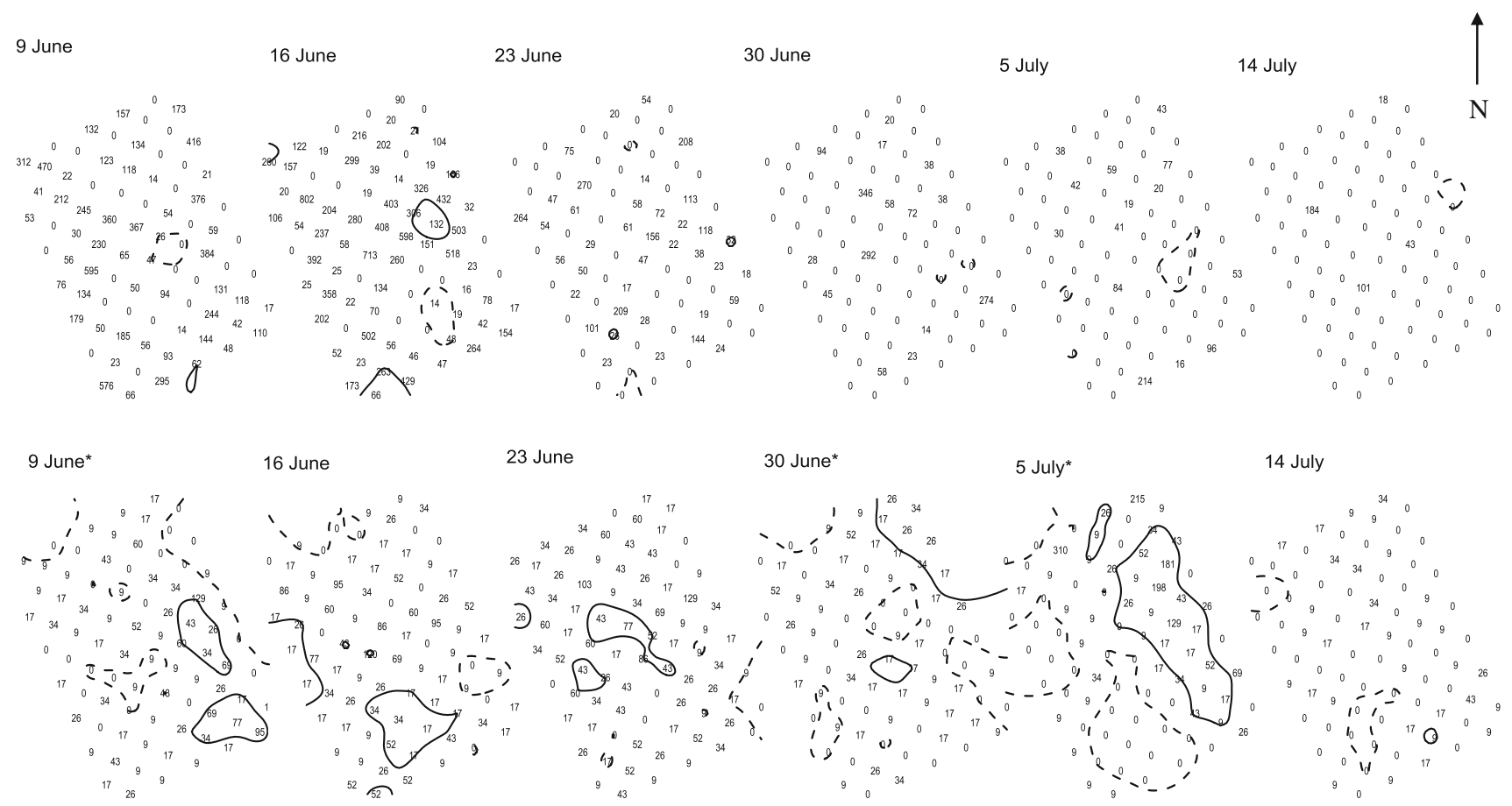

Fig. 6 Spatial pattern on each sampling date of M. dirhodum on the crop, number $\mathrm{m}^{-2}$ (upper series), and the ground, number $\mathrm{m}^{-2}$ day $^{-1}$ (lower series), for the field Oakmead

three of the five sampling dates (28 June, 5 July and 10 July), whilst none could be detected for M. dirhodum (Figs. 3, 4; Table 3). Local association between aphid density and falloff was detectable for $S$. avenae on the 9 June $(\chi=0.22$, $P=0.022)$ and 10 July $(\chi=0.32, P<0.01)$ and for $M$. dirhodum on the 10 July $(\chi=0.29, P<0.01)$.

For Oakmead, S. avenae and $M$. dirhodum populations peaked on 23 June and 16 June, respectively (Table 2). $S$. avenae slightly exceeded the damage threshold at flowering. Aphid spatial pattern within the fields was generally not evident (Figs. 5, 6; Table 4). S. avenae falloff exhibited spatial pattern towards the end of the season (5 and 14 July; Fig. 5; Table 4), whilst spatial pattern was also evident for $M$. dirhodum on three sampling dates (9 June, 30 June and 5 July; Fig. 6; Table 4). Local association between aphid density and fall-off was not detectable for either species, apart for $M$. dirhodum on the 9 June $(\chi=0.239, P=0.02)$.

There was a significant positive relationship between aphid density on the ears and the rate of fall-off for both S. avenae and M. dirhodum (Fig. 7). At a density of 50 aphids $\mathrm{m}^{-2}, 29$ and $46 \%$ of individuals fell to the ground day ${ }^{-1}$, and at a density of $500 \mathrm{~m}^{-2}, 18$ and $9 \%$ of individuals fell to the ground for $S$. avenae and $M$. dirhodum, respectively.

Aphids returning to the crop (Horseparks, 5 July)

For $S$. avenae, there was strong spatial pattern (Fig. 8), with a patch along the western field margin and two gap areas $\left(v_{\mathrm{i}}=1.51, P<0.01, v_{\mathrm{j}}=-1.559, P<0.01\right)$. Local association between aphid fall-off and return was also evident $(\chi=0.26, P=0.02)$, indicating that aphid return was predominantly occurring where aphid fall-off was high. Very few $M$. dirhodum were caught (20 individuals) on the climbing traps, so no analyses were possible. It was not known whether this was due to $M$. dirhodum being unable to re-climb or whether the traps were ineffective for this species.

Aphid days and crop characteristics

For Horseparks, local dissociation was evident between $S$. avenae aphid days and leaf nitrogen $(\chi=-0.28$, $P>0.99$ ). Dissociation was also evident to some extent for ear nitrogen, although the test statistic was marginally nonsignificant $(\chi=-0.21, P=0.953)$. Positive local association was evident between $M$. dirhodum and leaf nitrogen $(\chi=0.31, P<0.01 ; \chi=0.32, P<0.01)$. Hence, there was some indication that for $S$. avenae, patches of high aphid day loading were dissociated with crop nitrogen, whilst the opposite was the case for M. dirhodum. No measurable local association between crop yield and aphid days could be detected.

For Oakmead, S. avenae and M. dirhodum aphid days were not measurably associated or dissociated with ear or leaf nitrogen. $S$. avenae was locally dissociated with yield $(\chi=-0.22, P=0.98)$, whilst $M$. dirhodum was locally associated with yield $(\chi=0.25, P=0.02)$. 
(a) S. avenae

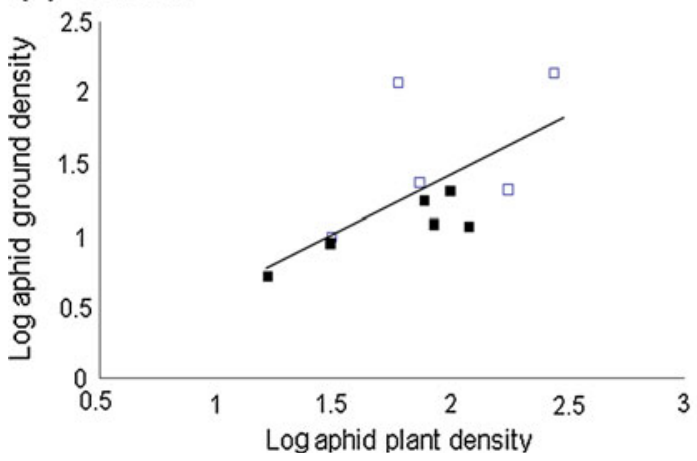

Fig. 7 Relationship between aphid density (D, number $\mathrm{m}^{-2}$ ) and falloff $\left(\mathrm{F}\right.$, number $\left.\mathrm{m}^{-2} \mathrm{day}^{-1}\right)$ for $\mathbf{a}$ S. avenae and $\mathbf{b} \mathrm{M}$. dirhodum for the fields Horseparks (open square) and Oakmead (filled square). Overall

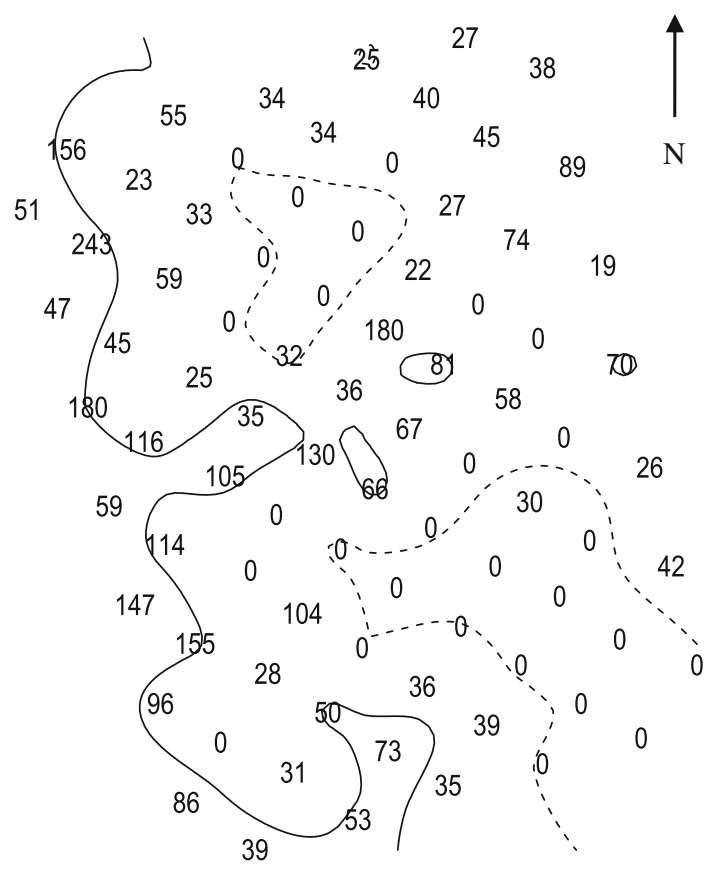

Fig. 8 Spatial pattern of $S$. avenae climb-back (total caught), recorded in an experiment conducted on the 5th July in Horseparks

\section{Discussion}

This intensive field study described aphid spatial pattern within two conventionally managed cereal fields. Within both fields, there was measurable pattern with regards to crop density, ear and leaf nitrogen, and soil moisture, yet we were unable to detect any spatial pattern with regard to yield in either field. The application of fertiliser may have overcome any natural variation in soil fertility, whilst variation in soil moisture may not have been sufficient to impact on yield. Aphid populations within the crop canopy at the field scale were largely spatially unstructured within both fields and for both species. However, at the local (b) M. dirhodum

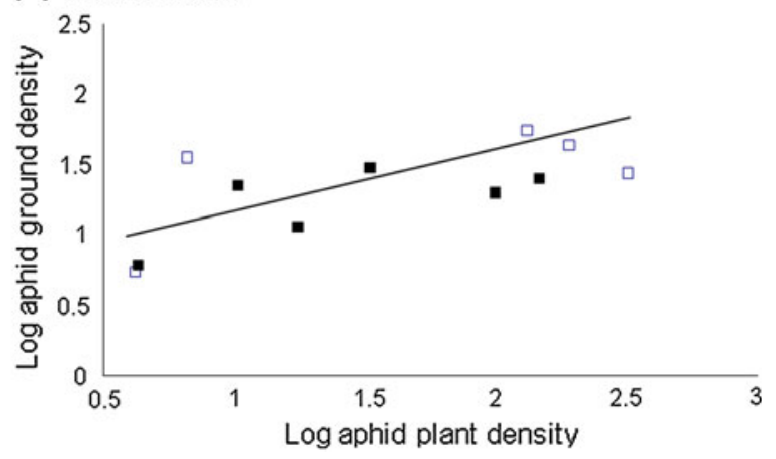

regression relationships: $S$. avenae- $\log _{10} \mathrm{~F}=0.78 \log _{10} \mathrm{D}-0.16$, $r=0.63, \quad P=0.04 ; \quad M . \quad$ dirhodum- $\log _{10} \mathrm{~F}=0.3 \log _{10} \mathrm{D}+0.84$, $r=0.67, P=0.02$

scale, aphid populations were associated or dissociated with the measured crop parameters, indicating possible linkage.

In Horseparks, S. avenae and M. dirhodum were locally dissociated and associated with crop nitrogen, and in Oakmead, the species were locally dissociated and associated with yield, respectively. M. dirhodum populations resided in the most productive parts of the field (Möwes et al. 1997; Honek 1991) and presumably had little effect on crop quality, whilst the more economically important $S$. avenae probably negatively influenced crop quality at the local scale, evidence by the dissociations we detected. This study was only based on two fields, so conclusions that could be drawn were limited. Further studies using more sophisticated measures of nitrogen, yield and soil moisture would further enhance our understanding of these processes. Although the fields were on the same farm, there were differences evident in aphid population growth, spatial structure and associations with crop parameters. The reason for these differences are unknown, but they probably relate to the initial conditions of the establishing aphid population (i.e. localised immigration of winged immigrants and the resident overwintering population), microclimatic and topographical differences, differences in soil fertility influencing crop growth and differences in the impact of natural enemies (Irwin et al. 2007; Evans 2008).

For $S$. avenae, spatial pattern within the crop was detected only late in the season, whilst we were able to detect emergence of strong spatial pattern for falling $S$. avenae much earlier in the season. We demonstrated limited local association between crop canopy aphid density and fall-off, although our expectation was that they would be closely linked. There are two likely explanations: either fall-off is not as strongly linked to the within-canopy population as we expected and might be influenced by other factors such as microclimate or the presence of 
Table 4 Mean cluster index $v_{\mathrm{i}}$ for patches and $v_{\mathrm{j}}$ for gaps, with associated probability, $P$, for the aphids $S$. avenae and $M$. dirhodum found on the crop and on the ground within the field Oakmead

\begin{tabular}{|c|c|c|c|c|c|c|c|c|c|}
\hline \multirow[t]{2}{*}{ Date } & \multirow[t]{2}{*}{ Cluster type } & \multicolumn{2}{|c|}{ S. avenae-crop } & \multicolumn{2}{|c|}{ S. avenae-ground } & \multicolumn{2}{|c|}{ M. dirhodum-crop } & \multicolumn{2}{|c|}{ M. dirhodum-ground } \\
\hline & & Cluster index & $P$ & Cluster index & $P$ & Cluster index & $P$ & Cluster index & $P$ \\
\hline \multirow[t]{2}{*}{9 June } & Patch & 0.93 & 0.57 & 0.87 & 0.82 & -0.95 & 0.57 & 1.32 & $0.04 *$ \\
\hline & Gap & -0.95 & 0.60 & -0.88 & 0.79 & 0.90 & 0.67 & -1.33 & $0.04 *$ \\
\hline \multirow[t]{2}{*}{16 June } & Patch & 0.88 & 0.73 & 1.04 & 0.30 & 1.01 & 0.34 & 1.20 & 0.09 \\
\hline & Gap & -0.90 & 0.72 & -1.06 & 0.27 & -0.97 & 0.52 & -1.22 & 0.09 \\
\hline \multirow[t]{2}{*}{23 June } & Patch & 1.03 & 0.31 & 0.83 & 0.70 & 0.94 & 0.59 & 1.17 & 0.13 \\
\hline & Gap & -1.03 & 0.35 & -0.90 & 0.92 & -0.94 & 0.60 & -1.17 & 0.13 \\
\hline \multirow[t]{2}{*}{30 June } & Patch & 1.01 & 0.40 & 1.10 & 0.20 & 0.83 & 0.92 & 1.33 & $0.04 *$ \\
\hline & Gap & -0.94 & 0.61 & -1.12 & 0.18 & -0.80 & 0.96 & -1.32 & $0.04 *$ \\
\hline \multirow[t]{2}{*}{5 July } & Patch & 1.04 & 0.26 & 1.34 & $0.04 *$ & 0.90 & 0.70 & 1.74 & $<0.01^{*}$ \\
\hline & Gap & -1.03 & 0.35 & -1.36 & $0.03 *$ & -0.90 & 0.68 & -1.83 & $<0.01 *$ \\
\hline \multirow[t]{2}{*}{14 July } & Patch & 1.39 & $0.02 *$ & 1.37 & $0.03 *$ & 0.84 & 0.87 & 1.00 & 0.41 \\
\hline & Gap & -1.52 & $<0.01^{*}$ & -1.66 & $<0.01 *$ & -0.81 & 0.90 & -1.01 & 0.38 \\
\hline \multirow[t]{2}{*}{ Aphid days } & Patch & 1.42 & $0.01^{*}$ & - & - & 0.96 & 0.47 & - & - \\
\hline & Gap & -1.51 & $<0.01 *$ & - & - & -1.00 & 0.43 & - & - \\
\hline
\end{tabular}

*Denotes where measurable spatial pattern could be detected

natural enemies. Alternatively, the field counts may have failed to characterise the within-canopy population effectively (Trumble et al. 1982) although previous studies using the same sampling intensity were able to detect pattern for S. avenae and M. dirhodum (Winder et al. 2001, 2005). For M. dirhodum, we found little evidence of spatial structure within either field, whilst aphid fall-off did exhibit spatial pattern, detected in both early and late season. We also demonstrated, albeit on only one sampling occasion and for one species ( $S$. avenae), that there was correspondence between aphid fall-off and their subsequent return to the crop canopy by climbing. This correspondence was probably due to aphids travelling only short distances before returning to the crop (Alyokhin and Sewell 2003).

Aphid spatial structure may also be created by differential predation levels within the field. Predation must be mediated to some extent by aphid fall-off as this is vital for ground-active predators that rely on this process to access aphid prey. Considerable variation in the activity of ground-active predators occurs during the growing season both within and between fields (Holland et al. 2009). Whether the spatial structure evident for aphid fall-off could mediate an aggregative numerical response for ground-active predators (Monsrud and Toft 1999; Harwood et al. 2001) warrants further study. There is some evidence that predators respond to aggregations of prey: for example, linyphiid spiders have been shown to construct webs where prey were relatively more abundant (Harwood et al. 2003; Harwood et al. 2004; Romero and Harwood 2010), whilst carabid predators such as Agonum dorsale Pont. may aggregate into areas of high aphid density (Bryan and
Wratten 1984; Winder et al. 2001). It is also known that ground-active predators can reduce return rates of aphids to the crop canopy (Winder 1990; Duffield et al. 1996). Recent evidence indicates that ground-active predators respond relatively slowly to aphid infestations and are less effective at providing control than aerial natural enemies, for example, parasitoids and syrphids (Schmidt et al. 2003; Schmidt et al. 2004; Holland et al. 2008, 2012). However, the contribution of different predatory guilds varied between these studies-being dependent on the local abundance of natural enemies varying across a range of scales from within-field to landscape (Tscharntke et al. 2007; Holland et al. 2009).

Further investigation into these effects would enhance our understanding of processes that regulate the biological control potential of natural enemies found within agroecosystems. Although a number of studies have been conducted that describe aphid fall-off, relatively little is known with regard to the mechanisms that cause it or indeed the proportion that are actually dead that might be scavenged rather than predated. It may be useful to focus further studies on the interaction between the aphid subpopulation resident on the ground rather than within the crop canopy itself, thereby revealing ground predator/prey interactions more effectively. Availability of aphids to ground-active predators is mediated by the rate at which aphids are dislodged and fall to the ground, and predatorpredator interactions that enhance predation rates are known to exist (Losey and Denno 1998; Griffiths et al. 2008). A better understanding of how pest control is delivered by a community of natural enemies would aid the 
development of integrated pest management, a practice that will become mandatory for all EU farmers from 2014 (Directive 209/128/EC).

Acknowledgments IACR-Rothamsted receives grant-aided support from the Biotechnology and Biological Sciences Research Council of the United Kingdom. We would like to thank the Seale-Hayne farm manager Richard Newington for providing assistance. We thank Jon Mellings, Sarah Oakes, Wayne Sweeting and Linda Hutchings for assistance with field work and Roger Wills for generously providing the field site. We would also like to thank three anonymous referees for their comments and suggestions, which substantially improved this paper.

Open Access This article is distributed under the terms of the Creative Commons Attribution License which permits any use, distribution, and reproduction in any medium, provided the original author(s) and the source are credited.

\section{References}

Alexander CJ, Holland JM, Winder L, Woolley C, Perry JN (2005) Performance of sampling strategies in the presence of known insect spatial pattern. Ann Appl Biol 146:361-370

Alyokhin A, Sewell G (2003) On-soil movement and plant colonization by walking wingless morphs of three aphid species (Homoptera: Aphididae) in greenhouse arenas. Environ Entomol 32(6):1393-1398

Annan IB, Schaefers GA, Saxena KN (1999) Pattern and rate of within-field dispersal and economic of the cowpea aphid, Aphis craccivora (Aphididae), on selected cowpea cultivars. Insect Sci Appl 19:1-16

Aqueel MA, Leather SR (2011) Effect of nitrogen fertilizer on the growth and survival of Rhopalosiphum padi (L.) and Sitobion avenae (F.) (Homoptera: Aphididae) on different wheat cultivars. Crop Prot 30:216-221

Basky Z, Fónagy A (2007) The effect of aphid infection and cultivar on the protein content governing baking quality of wheat flour. J Sci Food Agric 87:2488-2494

Bommarco R, Firle SO, Ekbom B (2007) Outbreak suppression by predators depends on spatial distribution of prey. Ecol Model 201:163-170

Bryan KM, Wratten SD (1984) The responses of polyphagous predators to prey spatial heterogeneity: aggregation by carabid and staphylinid beetles to their cereal aphid prey. Ecol Entomol 9:251-259

Chapin JW, Thomas JS, Gray SM, Smith DM, Halbert SE (2001) Seasonal abundance of aphids (Homoptera: Aphididae) in wheat and their role as barley yellow dwarf virus vectors in the South Carolina coastal plain. J Econ Entomol 94:410-421

Chaul A, Heinzl KM, Davies FT Jr (2005) Influences of fertilization on Aphis gossypii and insecticide usage. J Appl Entomol 129:89-97

Delin S (2004) Within-field variations in grain protein content: relationships to yield and soil nitrogen and consistency in maps between years. Precision Agric 5:565-577

Dixon AFG (1987) Cereal aphids as an applied problem. Agric Zool Rev 2:1-57

Duffield SJ, Jepson PC, Wratten SD, Sotherton NW (1996) Spatial changes in invertebrate predation rate in winter wheat following treatment with dimethoate. Entomol Exp Appl 78:9-17
Duffield SJ, Bryson RJ, Young JEB, Sylvester-Bradley R, Scott RK (1997) The influence of nitrogen fertiliser on the population development of the cereal aphids Sitobion avenae (F.) and Metopolophium dirhodum (Wlk.) on field grown winter wheat. Ann Appl Biol 130:13-26

Dutilleul P (1993) Modifying the t-test for assessing the correlation between two spatial processes. Biometrics 49:305-314

Ehsan-Ul-Haq, van Emden, HF (2002) Effect of varying levels of nitrogen and potassium on the development of Metopolophium dirhodum reared on a susceptible and a partially resistant cultivar of wheat. Pak J Zool 34:297-302

Ehsan-Ul-Haq, van Emden, HF (2003) Some effects of different soil moisture on development of Metopolophium dirhodum using a susceptible and partially resistant cultivar of wheat. Pak J Zool $35: 21-24$

Evans EW (2008) Multitrophic interactions among plants, aphids, alternate prey and shared natural enemies: a review. Eur $\mathrm{J}$ Entomol 105:369-380

Finke DL, Snyder WE (2008) Niche partitioning increases resource exploitation by diverse communities. Science 321:1488-1490

George KS, Gair R (1979) Crop loss assessment on winter wheat attacked by the grain aphid Sitobion avenae (F.), 1974-1977. Plant Pathol 28:143-149

Griffiths GJK, Wilby A, Crawley MJ, Thomas MB (2008) Densitydependent effects of predator species-richness in diversityfunction studies. Ecology 89:2986-2993

Harwood JD, Sunderland KD, Symondson WOC (2001) Living where the food is: web location by linyphiid spiders in relation to prey availability in winter wheat. J Appl Ecol 38:88-99

Harwood JD, Sunderland KD, Symondson WOC (2003) Weblocation by linyphiid spiders: Prey-specific aggregation and foraging strategies. J Anim Ecol 72:745-756

Harwood JD, Sunderland KD, Symondson WOC (2004) Prey selection by linyphiid spiders: molecular tracking of the effects of alternative prey on rates of aphid consumption in the field. Mol Ecol 10:3549-3560

Holland JM, Thomas CFG, Birkett T, Southway S (2007) Spatiotemporal distribution and emergence of beetles in arable fields in relation to soil moisture. Bull Entomol Res 97:89-100

Holland JM, Oaten H, Southway S, Moreby S (2008) The effectiveness of field margin enhancement for cereal aphid control by different natural enemy guilds. Biol Control 47:71-76

Holland JM, Birkett T, Southway S (2009) Contrasting the farm-scale spatio-temporal dynamics of boundary and field overwintering predatory beetles in arable crops. Biocontrol 54:19-33

Holland JM, Oaten H, Birkett TC, Simper J, Southway S, Smith BM (2012) Agri-environment scheme enhancing ecosystem services: a demonstration of improved biological control in cereal crops. Agric Ecosyst Environ 155:147-152

Honek A (1991) Nitrogen fertilization and abundance of the cereal aphids Metopolophium dirhodum and Sitobion avenae (Homoptera, Aphididae). Zeitschrift fur Pflanzenkrankheiten und Pflanzenschutz 98:655-660

Honêk A, Martinková Z (2002) Factors of between- and within-plant distribution of Metopolophium dirhodum (Hom., Aphididae) on small grain cereals. J Appl Entomol 126:378-383

Irwin EI, Kampmeier GE, Weisser WW (2007) Aphid movement: process and consequences. In: van Emden H, Harrington R (eds) Aphids as crop pests. CAB International, Wallingford, pp 153-186

Kerzicnik LM, Peairs FB, Harwood JD (2010) Implications of Russian wheat aphid, Diuraphis noxia, falling rates for biological control in resistant and susceptible winter wheat. ArthropodPlant Interact 4:129-138

Khan M, Port G (2008) Performance of clones and morphs of two cereal aphids on wheat plants with high and low nitrogen content. Entomol Sci 11:159-165 
Losey JE, Denno RF (1998) Positive predator-predator interactions: enhanced predation rates and synergistic suppression of aphid populations. Ecology 79:2143-2152

Minoretti N, Weisser WW (2000) The impact of individual ladybirds (Coccinella septempunctata, Coleoptera: Coccinellidae) on aphid colonies. Eur J Entomol 97:475-479

Monsrud C, Toft S (1999) The aggregative numerical response of polyphagous predators to aphids in cereal fields: attraction to what? Ann Appl Biol 134:265-270

Möwes M, Freier B, Heimann J (1997) Variation in yield loss per aphid-day due to Sitobion avenae-infestation in high yielding winter wheat. Zeitschrift fur Pflanzenkrankheiten und Pflanzenschutz 104:569-575

Perry JN, Dixon PM (2002) A new method to measure spatial association for ecological count data. Ecoscience 9:133-141

Perry JN, Winder L, Holland JM, Alston RD (1999) Red-blue plots for detecting clusters in count data. Ecol Lett 2:106-113

Romero S, Harwood JD (2010) Prey utilization by a community of linyphiid spiders: variation across diel and seasonal gradients. Biol Control 52:84-90

Rowntree JK, McVennon A, Prezios RF (2010) Plant genotype mediates the effects of nutrients on aphids. Oecologia 163: 675-679

Ruppel RF (1983) Cumulative insect-days as an index of crop protection. J Econ Entomol 76:375-377

Schmidt MH, Lauer A, Purtauf T, Thies C, Schaefer M, Tscharntke T (2003) Relative importance of predators and parasitoids for cereal aphid control. Proc Royal Soc London B Biol Sci 270: 1905-1909

Schmidt MH, Thewes U, Thies C, Tscharntke T (2004) Aphid suppression by natural enemies in mulched cereals. Entomol Exp Appl 113:87-93

Sopp PI, Sunderland KD, Coombes DS (1987) Observations on the number of cereal aphids on the soil in relation to aphid density in winter wheat. Ann Appl Biol 111:53-57
Sunderland KD, Fraser AM, Dixon AFG (1986) Field and laboratory studies on money spiders (Linyphiidae) as predators of cereal aphids. J Appl Ecol 23:433-447

Symondson WOC, Sunderland KD, Greenstone MH (2002) Can generalist predators be effective biocontrol agents? Annu Rev Entomol 47:561-594

Trumble JT, Nakakihara H, Zehnder GW (1982) Comparisons of traps and visual searches of foliage for monitoring aphid (Heteroptera: Aphididae) population density in broccoli. J Econ Entomol 75:853-856

Tscharntke T, Bommarco R, Clough Y, Crist TO, Kleijn D, Rand TA, Tylianakis JM, van Nouhuys S, Vidal S (2007) Conservation biological control and enemy diversity on a landscape scale. Biol Control 43:294-309

van Emden HF, Harrington R (eds) (2007) Aphids as Crop Pests. CABI, Wallingford

Winder L (1990) Predation of the cereal aphid Sitobion avenae by polyphagous predators on the ground. Ecol Entomol 101: 569-574

Winder L, Hirst DJ, Carter N, Wratten SD, Sopp PI (1994) Estimating predation of the grain aphid Sitobion avenae by polyphagous predators. J Appl Ecol 31:1-12

Winder L, Perry JN, Holland JM (1999) The spatial and temporal distribution of the grain aphid Sitobion avenae in winter wheat. Entomol Exp Appl 93:277-290

Winder L, Alexander CJ, Holland JM, Woolley C, Perry JN (2001) Modelling the dynamic spatio-temporal response of predators to transient prey patches in the field. Ecol Lett 4:568-576

Winder L, Griffiths GJK, Perry JN, Alexander CJ, Holland JM, Kennedy PJ, Birt A (2005) The role of large-scale spatially explicit and small-scale localized processes on the population dynamics of cereal aphids. Bull Entomol Res 95:579-587

Zadoks JC, Chang TT, Konzak CF (1974) A decimal code for the growth stages of cereals. Weed Res 14:415-421 